\title{
Acute type A, B, and non-A, non-B hepatitis in a hospital population in London: clinical and epidemiological features
}

\author{
MAY BAMBER, HOWARD C THOMAS, \\ BARBARA BANNISTER, AND SHEILA SHERLOCK
}

From the Department of Medicine, The Royal Free Hospital, Pond Street, Hampstead, London, and the Infectious Diseases Department, The Royal Free Hospital, Coppett's Wood Hospital, London

SUMMARY The aetiology of acute viral hepatitis in 172 patients admitted to an infectious diseases hospital in North London was: hepatitis A in 88 (51\%), hepatitis B in $58(34 \%)$, Epstein-Barr (EB) virus in four (2\%) and non-A, non-B in $22(13 \%)$. NANB hepatitis was a milder disease than that associated with the other viruses. It predominantly occurred in young men (77\%). In half of the cases there was evidence of parenteral transmission. It was not transmitted by sexual contact.

Since the introduction of radioimmunoassays for the diagnosis of hepatitis $\mathrm{A}$ and $\mathrm{B}$ virus infection, it has become apparent that other hepatitis viruses, designated non-A, non-B (NANB), exist.

Approximately four to $18 \%$ of patients receiving blood transfusions, when followed prospectively, develop NANB hepatitis. ${ }^{1}$ The disease has also been shown to occur in patients with coagulation disorders who are receiving clotting factors, ${ }^{23}$ in haemodialysis patients, ${ }^{45}$ in epidemic form, ${ }^{67}$ and as sporadic cases. ${ }^{8-11}$

Our knowledge of the prevalence and clinical characteristics of NANB hepatitis in the United Kingdom is still incomplete. The purpose of our study was to: (a) assess the importance of NANB virus infection as a cause of acute hepatitis in patients admitted to an infectious diseases hospital, and (b) investigate the clinical characteristics of NANB hepatitis in such a hospital population.

\section{Methods}

PATIENTS

The Infectious Diseases Department at Coppett's Wood Hospital serves approximately one million people. Large numbers of patients with suspected

Address for correspondence: Dr May Bamber, Department of Medicine, Royal Free Hospital School of Medicine, (University of London), London NW3 2PF.

Received for publication 10 September 1982 acute viral hepatitis are admitted, either referred by their general practitioners or by other hospitals. The study was conducted on 172 patients over the age of 15 years, between 1 August 1980 and 31 July 1981. Acute phase serum was obtained immediately after admission and thereafter at weekly intervals. Acute viral hepatitis was diagnosed if the clinical picture was compatible and if the aspartate transaminase was raised to more than $2 \cdot 5$ times the upper limit of the normal range. After discharge patients were followed-up in an outpatient clinic, for clinical and biochemical assessment and collection of convalescent serum.

Acute hepatitis A was diagnosed if IgM antibody to the hepatitis A virus (IgM anti-HAV) was present in the acute phase of the infection. IgM anti-HAV was measured by radioimmunoassay (RIA) (HAVAB: Abbott Laboratories). Acute hepatitis B was diagnosed if hepatitis $B$ surface antigen, also measured by RIA (AUSRIA: Abbott Laboratories) was positive or if the antibody to hepatitis $B$ core antigen (HBcAb) was positive in the absence of antibody to the hepatitis $B$ surface antigen, (HBsAb).

Patients without markers for acute hepatitis A or $B$ virus infection were tested for IgM and IgG antibody to EBV by indirect immunofluorescence and for a changing titre of antibody to CMV, by complement fixation test.

If all the above serological investigations were negative and if the patient had not abused alcohol 
(intake of greater than $80 \mathrm{~g} /$ day), not been exposed to hepatotoxic drugs and had no history of chronic liver disease, a diagnosis of NANB hepatitis was made.

\section{Results}

Of the 172 patients who were studied, $88(51 \%)$ were positive for IgM anti-HAV in the acute episode, $58(34 \%)$ for HBsAg and four $(2 \%)$ had clinical and serological evidence of EBV infection. Twenty two patients (13\%) were negative for markers of acute type A and B hepatitis, EBV and CMV infection, so were classified as NANB (Table 1).

\section{EPIDEMIOLOGICAL, CLINICAL, AND BIOCHEMICAL} FEATURES

NANB resembled both $A$ and $B$ hepatitis in that over $70 \%$ of cases were seen in young adults of 15-29 years of age (Figure). Like hepatitis A and B infection there was a predominant occurrence in men (hepatitis A 71\%, hepatitis B 83\%, hepatitis NANB $77 \%$ ). The possible sources of infection are shown in Table 2. Half of the patients with NANB hepatitis were parenteral drug abusers as opposed to $40 \%$ in hepatitis B group. Three NANB hepatitis patients $(14 \%)$ had travelled overseas (two of them to India) in the three months before the onset of their acute hepatitis, two $(9 \%)$ had received blood transfusions one month before they became symptomatic, two $(9 \%)$ had had needlestick exposure and two $(9 \%)$ were living in hostels. One patient $(5 \%)$ had had dental treatment. No patients in the NANB group had had sexual contact with known hepatitis cases. In contrast $24 \%$ of both hepatitis A and B patients had had homosexual exposure. Three per cent of the hepatitis B patients had had heterosexual contact. In $14 \%$ of the patients with NANB hepatitis the possible source of infection was not known.

Fifty-two per cent of the patients with NANB hepatitis had a peak serum bilirubin of less than 86 $\mu \mathrm{mol} / \mathrm{l}$, in contrast with $16 \%$ of patients with hepatitis B and $28 \%$ with hepatitis A (Table 3).

Table 1 Acute viral hepatitis: aetiology

\begin{tabular}{lcr}
\hline Aetiology & Patients (no) & $\%$ \\
\hline Hepatitis A & 88 & 51 \\
Hepatitis B & 58 & 34 \\
Hepatitis EBV & 4 & 2 \\
Hepatitis CMV & 0 & 0 \\
Hepatitis NANB & 22 & 13 \\
& 172 & 100 \\
\hline
\end{tabular}
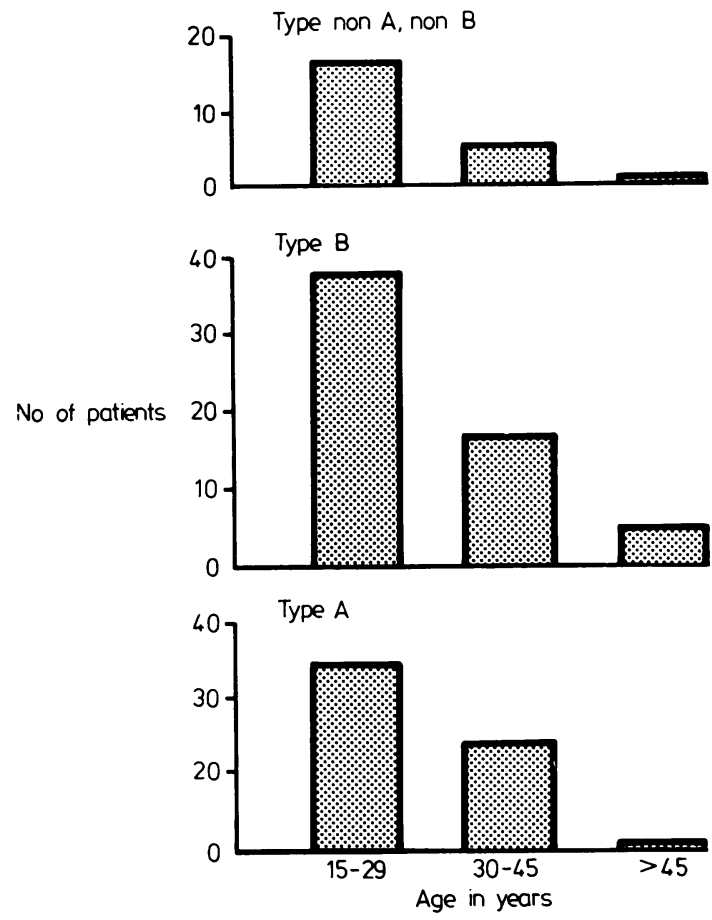

Figure Age distribution in acute $A, B$, and non- $A$, non- $B$ hepatitis.

None of the patients with NANB had a peak serum bilirubin above $259 \mu \mathrm{mol} / \mathrm{l}$. Eighty-one per cent showed a peak aspartate transaminase (AST) of less than $400 \mathrm{IU} / \mathrm{l}$ and none exceeded a concentration of $800 \mathrm{IU} / \mathrm{l}$ (Table 3).

Table 4 shows the incidence of prodromal features in the three types of viral hepatitis. Twenty-seven per cent of patients with hepatitis A or NANB had a

Table 2 Epidemiological factors in acute viral hepatitis

\begin{tabular}{lrrr} 
& $\begin{array}{c}A \\
(\%)\end{array}$ & $\begin{array}{l}\boldsymbol{B} \\
(\%)\end{array}$ & $\begin{array}{l}\text { NANB } \\
(\%)\end{array}$ \\
\hline IV drug abuse & 0 & 40 & 50 \\
Needlestick exposure & 0 & 4 & 9 \\
Overseas travel & 26 & 9 & 14 \\
Contacts & & & \\
$\quad$ Non-sexual & 16 & 0 & 0 \\
$\quad$ Homosexual & 24 & 24 & 0 \\
$\quad$ Heterosexual & 1 & 3 & 0 \\
Therapeutic intervention & 1 & 9 & 5 \\
Blood transfusion & 0 & 0 & 9 \\
Institutional dwelling & 0 & 0 & 9 \\
Possible contaminated food & 9 & 0 & 5 \\
Unknown & 23 & 17 & 14 \\
\hline
\end{tabular}


Table 3 Peak serum bilirubin and aspartate transaminase in adults with acute viral hepatitis

\begin{tabular}{|c|c|c|c|c|c|c|c|}
\hline $\begin{array}{l}\text { Peak serum } \\
\text { bilirubin } \\
\text { umol/l }\end{array}$ & $\begin{array}{l}N A N B \\
(\%)\end{array}$ & $\begin{array}{l}B \\
(\%)\end{array}$ & $\begin{array}{l}A \\
(\%)\end{array}$ & $\begin{array}{l}\text { Peak serum } \\
\text { aspartate } \\
\text { trans- } \\
\text { aminase } \\
(\mathrm{IU} / \mathrm{I})\end{array}$ & $\begin{array}{l}N A N B \\
(\%)\end{array}$ & $\begin{array}{l}B \\
(\%)\end{array}$ & $\begin{array}{l}A \\
(\%)\end{array}$ \\
\hline 86 & 52 & 16 & 28 & 400 & 81 & 24 & 55 \\
\hline $87-171$ & 24 & 43 & 53 & $401-800$ & 19 & 40 & 24 \\
\hline $172-259$ & 24 & 19 & 15 & $801-1200$ & 0 & 19 & 7 \\
\hline 259 & 0 & 22 & 2 & $>1200$ & 0 & 17 & 11 \\
\hline
\end{tabular}

fever usually rising to no more than $38.5^{\circ} \mathrm{C}$ in contrast with only $5 \%$ of patients with hepatitis B. Only $7 \%$ of patients with hepatitis B developed arthralgia of the large joints lasting two to five days. These symptoms were more common in the NANB group and affected the same joints. Transient macular rashes occurred rarely in all groups.

We were able to carry out adequate follow up that is, either until biochemical and clinical recovery was established or for six months after the onset of the acute hepatitis - on 12 patients with NANB hepatitis, 60 with type A hepatitis, and 34 with type $B$ hepatitis. Table 5 shows the duration of hepatitis in each group. Two patients in the NANB group $(18 \%)$ still showed fluctuating transaminases seven months after the onset in contrast with two patients $(6 \%)$ with hepatitis $B$, and none with hepatitis $A$.

None of the patients with NANB hepatitis showed any complications or episodes of relapse. This contrasts with those patients with type A hepatitis of whom three relapsed and one developed a transitory rise in his urea concentration to four times the upper limit of normal. There were no patients in either the NANB or A groups who suffered from fulminant hepatitis, but one patient with type B hepatitis developed this complication and died (Table 6).

\section{Discussion}

We have prospectively studied the prevalence, epidemiology and clinical aspects of acute NANB, $A$ and $B$ hepatitis in an infectious diseases hospital population. Our finding of a $13 \%$ prevalence rate

Table 4 Clinical features of acute viral hepatitis

\begin{tabular}{llll}
\hline & $\begin{array}{l}\text { Fever } \\
(\%)\end{array}$ & $\begin{array}{l}\text { Arthralgia } \\
(\%)\end{array}$ & $\begin{array}{l}\text { Rash } \\
(\%)\end{array}$ \\
\hline A & 27 & 11 & 1 \\
B & 5 & 7 & 7 \\
NANB & 27 & 18 & 5 \\
\hline
\end{tabular}

Table 5 Follow up of patients with acute viral hepatitis

\begin{tabular}{llllr}
\hline & Weeks & NANB & $B$ & $A$ \\
\hline Recovered & $<12$ & 4 & 16 & 23 \\
& $12-24$ & 3 & 14 & 31 \\
\multirow{2}{*}{ Not recovered } & $24-28$ & 3 & 2 & 6 \\
\hline
\end{tabular}

for NANB hepatitis is similar to other published data.

NANB hepatitis occurred predominantly in young men. In contrast with the study of Farrow et al, ${ }^{12}$ conducted in West London, $50 \%$ of our NANB patients were intravenous drug abusers, $9 \%$ had had needlestick exposure, $9 \%$ blood transfusions and $14 \%$ had recently travelled abroad, two to India. The observation of a high incidence of drug abuse is in keeping with a number of other studies in Scandinavia and Australia. ${ }^{1314}$ The association between NANB hepatitis and blood transfusions is now well recognised, especially in the United States. ${ }^{15-17}$ Both our patients who developed posttransfusion NANB hepatitis had an incubation period of four weeks. Both made an uneventful recovery. Our finding that two patients had travelled to India in the three months before the onset of acute hepatitis is of interest as they may have been infected with the water-borne NANB viruses that have been described in epidemic form in India. ${ }^{6}$ We found no evidence of sexual transmission either homosexual or heterosexual. In contrast, $24 \%$ of patients with type A hepatitis were homosexual men as was an approximately equal proportion amongst the hepatitis B cases. The occurrence of hepatitis A in homosexual men may be because of oral sexual practices as suggested by Corey et al. ${ }^{18}$

We observed that NANB hepatitis is a mild disease, in keeping with other studies, ${ }^{19-21}$ but that in $10 \%$ of cases transaminases may still be raised seven months after the onset of the disease. All of these patients had evidence of possible parenteral transmission. This incidence of chronicity is in accord with previous studies of parenterally transmitted NANB hepatitis in which rates of $20-90 \%$ chronicity have been recorded. ${ }^{22}{ }^{23}$ In the

Table 6 Morbidity and mortality in acute viral hepatitis

\begin{tabular}{llll}
\hline & \multicolumn{2}{l}{ No $(\%)$} & \\
\cline { 2 - 4 } & NANB & $A$ & $B$ \\
\hline Relapse & 0 & $3(3)$ & 0 \\
Acute uraemia & 0 & $1(1)$ & 0 \\
Fulminant hepatitis & 0 & 0 & $1(2)($ died) \\
\hline
\end{tabular}


remaining patients the route of infection was unknown. This group of patients recovered within six months and in this respect is similar to other reports of sporadic NANB in Britain and North America, ${ }^{22}$ and to epidemic NANB hepatitis reported in Delhi and Kashmir. ${ }^{6}{ }^{7}$ It seems probable that sporadic as well as epidemic NANB hepatitis is enterally transmitted. From these studies it seems likely that parenterally transmitted but not sporadic and epidemic forms of NANB hepatitis are causes of chronic liver disease. Further studies are indicated to determine the natural history of these forms of hepatitis.

We thank Drs RTD Emond and Hillas Smith for allowing us study patients under their care. M Bamber is supported by the Medical Research Council, and HC Thomas is a Senior Wellcome Fellow.

\section{References}

1 Aach RD, Szmuness W, Mosley JW et al. Serum alanine aminotransferase of donors in relation to the risk of non-A, non-B hepatitis in recipients. $N$ Engl J Med 1981; 304: 989-94.

2 Craske J, Dilling N, Stern D. An outbreak of hepatitis associated with intravenous injection of factor VIII concentrate. Lancet 1975; 2: 221-3.

3 Bamber M, Murray A, Arborgh BAM et al. Short Incubation non- $A$, non-B hepatitis transmitted by factor VIII concentrates in patients with congenital coagulation disorders. Gut 1981; 22: 854-9.

4 Coursaget $\mathrm{P}$, Maupas $\mathrm{P}$, Dubois F, Drucker J, Goudeau A. Hepatitis non-A, non-B in six haemodialysed patients. Nouv Presse Med 1978; 7:3515-9.

5 Galbraith RM, Portman B, Eddleston ALWF, Williams $R$, Gower PE. Chronic liver disease developing after outbreak of $\mathrm{HBsAg}$ negative hepatitis in haemodialysis unit. Lancet 1975; 2: 886-9.

6 Wong DC, Purcell RH, Sreenirasan MA, Prasad SR, Pavri KM. Epidemic and endemic hepatitis in India: evidence for a non-A, non-B hepatitis virus etiology. Lancet 1980; 2: 876-8.

7 Khuroo MS. Study of an epidemic of non-A, non-B hepatitis. Possibility of another human hepatitis virus distinct from post-transfusion non-A, non-B hepatitis. Am J Med 1980; 68: 818-24.

8 Villajeros VM, Visona KA, Eduarte CA, Provost PJ, Hilleman MR. Evidence for viral hepatitis other than type A or type B among persons in Costa Rica. N Engl J Med 1975; 293:1350-2.

9 Dienstag JL, Alaama A, Mosley JW, Redeker AG, Purcell RH. Etiology of sporadic hepatitis B surface antigen-negative hepatitis. Ann Intern Med 1977; 87: $1-6$.

10 Muller R, Willers H, Frosner GG, Gerich W, Knocke KW, Sipos S, Deicher H, Hopken W. The seroepidemiological pattern of acute viral hepatitis in the Hanover area. Infection 1978; 6: 65-70.

11 Locarnini SA, Gust ID, Ferris AA, Stott AC, Wong ML. A prospective study of acute viral hepatitis with particular reference to hepatitis A. Bull WHO 1976; 54: 199-206.

12 Farrow LJ, Stewart JS, Stern H, Clifford RE, Smith HG. Epidemiological and prognostic aspects of hepatitis A, B, and non-A, non-B. Scand J Infect Dis suppl 1978; 17: 1-44.

13 Norkrans G. Clinical epidemiological and prognostic aspects of hepatitis A, B, and non-A, non-B. Scand J Infect Dis suppl 1978; 17: 1-44.

14 Gust ID, Lehmann NI, Lucas CR, Ferris AA, Locarnini SA. Studies on the epidemiology of hepatitis A in Melbourne. In: Vyas GN, Cohen SN, Schmid R, eds. Viral hepatitis. Philadelphia: Franklin Institute Press, 1978: 105.

15 Alter HJ. The dominant role of non-A, non-B in the pathogenesis of post-transfusion hepatitis: a clinical assessment. In: Sherlock S, ed. Clinics in Gastroenterology New York: Saunders, 1980: 155-70.

16 Prince AM, Brotman B, Grady GF, Kukus WJ, Hazzi $\mathrm{C}$, Levine RW, Milliam SJ. Long-incubation posttransfusion hepatitis without serological evidence of exposure to hepatitis B virus. Lancet 1974; 2: 241-6.

17 Knodell RG, Conrad ME, Ishak KG. Development of chronic liver disease after acute non-A, non-B posttransfusion hepatitis: role of gamma globulin prophylaxis in its prevention. Gastroenterology 1977; 72: 902-9.

18 Corey L, Holmes K. Sexual transmission of hepatitis A in homosexual men. $N$ Engl J Med 1980; 302: 435-8.

19 Purcell RH, Alter HJ, Dienstag JL. Non-A, non-B hepatitis. Yale J Biol Med 1976; 49: 243-50.

20 Alter HJ, Purcell RH, Holland PV, Feinstone SM, Morrow AG, Moritsugu Y. Clinical and serological analysis of transfusion - associated hepatitis. Lancet 1975; 2: 838-48.

21 Aach RD, Lander JJ, Sherman LA et al. Transfusion transmitted viruses: interim analysis of hepatitis among transfused and non-transfused patients. In: Vyas GN, Cohen SN, Schmid R, eds. Viral hepatitis. Philadelphia: Franklin Institute Press, 1978: 383.

22 Rakela J, Redeker AG. Chronic liver disease after acute non-A, non-B viral hepatitis. Gastroenterology 1979; 77: 1200-2.

23 Thomas HC, Bamber M, Kernoff PBA. Clinical, immunological and histological aspects of non-A, non-B hepatitis in haemophiliacs. In: Forbes CD, Lowe GDO, eds. Unresolved problems in haemophilia. Lancaster: MTP Press, 1982: 27-36.

24 Bamber M, Murray AK, Weller IVD et al. Clinical and histological features of a group of patients with sporadic non-A, non-B hepatitis. J Clin Pathol 1981; 34: $1175-80$. 